\title{
Ecosystem services in the spatial policy of environmentally protected communes
}

\author{
M. Hełdak \& B. Raszka \\ Department of Spatial Management, \\ Wroclaw University of Environmental and Life Sciences, Poland
}

\begin{abstract}
This paper undertakes the subject of ecosystem services used in evaluating the relations between the environment and humans, also in the area of spatial policy and environmental development. The studied areas were selected according to the services which are provided. There are those which have to do with giving something (Latin dare), doing something (facere), not doing something (non facere) or enduring something (pati). During the course of study, the types of ecosystem services in the environmentally protected communes localised in the vicinity of Wrocław (Mietków, Kąty Wrocławskie, Sobótka, Jordanów) were defined in the following categories: ecosystem services for the benefit of humans, human services for the benefit of the ecosystem (compensation), as well as preventive and retardant actions. The research involved an analysis of the planning documents defining spatial policy with regard to ecosystem services, followed by a statistical analysis of the results.

Keywords: ecosystem services, spatial policy.
\end{abstract}

\section{Introduction}

Numerous research disciplines study the use of environmental resources by humans. The ecosystem services theory can also be applied in the planning of the spatial development in the area of spatial economy, which is currently considered an element of social sciences related to economy in Poland. It is also an aspect of environmental and technical sciences. In its complexity, spatial economy binds ecology with economy.

According to Solon [1], the concept of ecosystem services is one of the tools for discussing the subject of relations between society and nature. It enables one 
to synthetically represent the connections between the basic concepts of ecology and those of economy, which, as a result, leads to a unified representation of economic and ecological evaluations.

The publishing of an article on the subject of the value of ecosystem services on a global scale in the context of the environmental capital of the Earth, played a major role in the formation of the ecosystem services concept $[2,3]$. Seventeen ecosystem functions have been singled out and paired with their respective ecosystem services, with both their non-material benefits and material goods included. A different classification of services has been provided by De Groot et al. [4]. He distinguishes various functions of ecosystems and connects them with separate services and goods retrieved from the ecosystems. These categories are shown as rich in ecological, socio-cultural and economical values beneficial to humans. Costanza et al. [3] claims that these quantities are not stable but evolve along with social goals, which determine the guidelines for defining benefits and costs.

A coherent set of ecosystem services is a perfect tool for educating local societies and politicians about the dependence of humans from nature and about the need for sustainable development [1,3-10].

From among the various ways of identifying and evaluating ecosystem services one can also point out approaches based on expert evaluation, taking into account the views of those who use the land [6]. The goal of this approach is a pseudo-quantitative evaluation of the indispensability and accessibility of services for various forms of land use. The resulting data gathered in relation tables can then be analysed with regard to the proper manner of land use, the scenarios for changes in spatial development, the economic, social and ecological consequences of exploiting resources and planning protective action (from [1]).

Currently, the local level spatial policy realised in Poland does not have any tools for the verifying of inclinations by local authorities to designate new areas for construction. At the same time, however, the little free space still available to us is shrinking under the influence of the development of settlement functions. We ask ourselves, how to make the local authorities and the residents of a given commune understand the danger related to the uninhibited craving for developing built-up areas. A synthetic description of planned purpose according to the approved theory of ecosystem services will allow us to show the scale of planned changes or e.g. point out the places where the project is lacking.

The aim of this paper is to analyse planning documents defining spatial policy with regard to ecosystem services, according to an approved original scheme of the relations between the environment and the economic (spatial) development of a commune. The research was conducted in Poland, in selected, environmentally protected communes of the Wrocław poviat.

This issue is a new element for scientific study in Poland. Globally, it was brought up near the late 90s [3] (the above-mentioned concept of seventeen types of ecosystem services and an evaluation of their economical value on a global scale), but the deepest roots of the ecosystem services concept are to be found in works by $19^{\text {th }}$ century biologists, who pointed out the "life-sustaining" functions 
of ecosystems [11]. Currently, the recognized division of ecosystem services distinguishes four groups [12]: provisioning services, regulating services, supporting services and cultural services. These focus on separate issues concerned with the relations between society, space and services.

\section{Methodology}

The study is concerned with the subject of ecosystem services, used in the evaluation of the relations between the environment and humans, also in the area of spatial policy and environmental development. The designation of areas for various goals in spatial policy in Poland is based on a hierarchical system of goals: country-voivodship-commune, but it is eventually realised on the local level. Planning and spatial development is essential in creating spatial order, while local plans formulated on the basis of spatial policy are the basic tools of localising various functions in space. For the purpose of this study, in the context of planning future spatial development of the commune, the authors have selected areas within which the services involve giving something (Latin dare), doing something (facere), not doing something (non facere) and enduring something (pati).

In the protected communes localised in Poland, in the vicinity of Wrocław (Mietków, Kąty Wrocławskie, Sobótka, Jordanów), the following categories have been used to define the types of ecosystem services: ecosystem service for the benefit of humans, human service for the benefit of the ecosystem (compensation), as well as preventive and retardant actions.

The ecosystem services for the benefit of humans group include the destination and use of area for residential-service developments, for economic activity, for surface exploitation of aggregate, for tourist purposes and for cemeteries. The human services for the benefit of the ecosystem group include the destination and use of land for forests, agricultural area, park greenery and open waters. Preventive and retardant actions include afforestations, operational and planned sewage plants and organised landfill sites.

In the course of the study, planning documents determining the spatial policy of communes have been analysed with regard to the approved ecosystem services. A statistical analysis of the results followed. Before the research took place, the area of the communes had been classified with regard to their current state of development. The data regarding the current use of land had been retrieved from the Local Data Bank, a division of the Central Statistical Office in Poland.

\section{Identifying zones in communes according to their current manner of use}

The communes selected for research are located within the sphere of influence of the city of Wrocław. The areas of the communes are under partial protection within established natural landscape parks. The Ślęża Landscape Park is located within the communes Sobótka and Jordanów Śląski, while the Bystrzyca Valley 
Landscape Park is located in Sobótka, Mietków and Kąty Wrocławskie. The Ślęża Landscape Park is located in the Sudetic Foothills. The Ślęża Massif, Kiełczyńskie Hills and Jańska Mountain are located within the park. Ślęża is the highest peak (718 m.a.s.1.). The forests are mostly mixed, comprising of spruce, maple, beech and birch trees. More than 380 species of plants grow in the area, including protected ones. The Ślęża Massif is an old cult site with some of the oldest settlement traces in Poland. The entire park consists of numerous archaeological sites, architectural and artistic monuments, cult statues and mining fields.

The Bystrzyca Valley Landscape Park was founded in 1998. It encompasses areas located in the Nizina Śląska. The Bystrzyca river constitutes the park's main axis and is one of the most important confluences of the Odra river. The park combines forest areas characteristic of the Sudetes with one of the most regularly formed wildlife corridors in the Odra Valley. It also contains one of the major water basins in the Lower Silesia - the Mietkowskie Lake, used mostly for aggregate excavation but also for recreation and angling.

Figure 1 represents the overall characteristics of the current manner of land use in each commune.

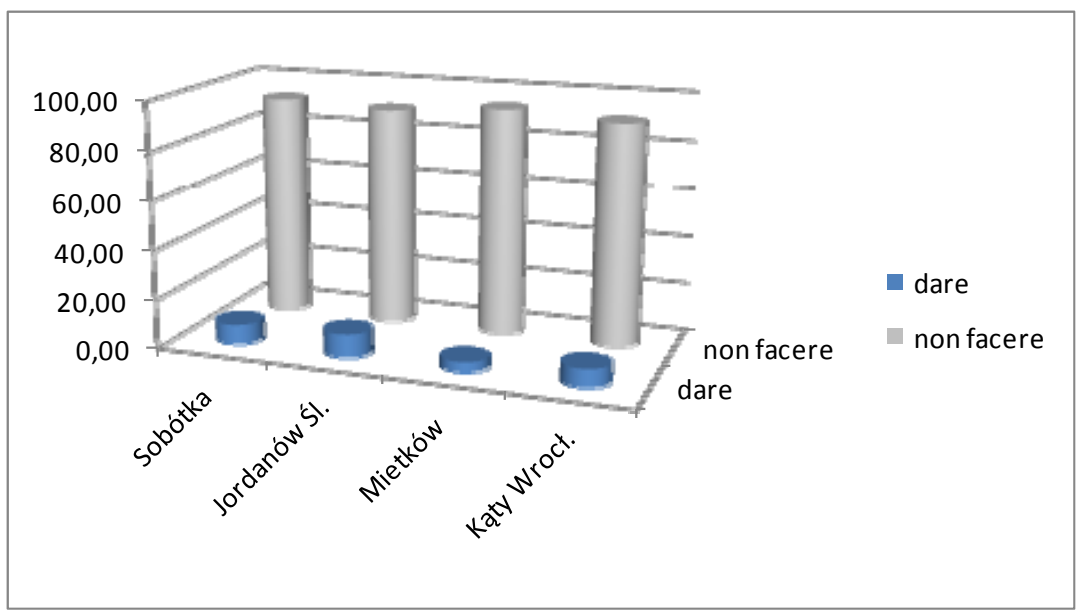

Figure 1: The current manner of land use in the commune divided to areas providing services for the benefit of humans and areas related to human services for the benefit of the ecosystem (not doing anything_Latin non facere).

The dominant type of land in the communes is agricultural land, which constitutes $68.42 \%$ of total area in the Sobótka commune, up to $86.54 \%$ in Jordanów. Forest areas are second when it comes to their share in the total area of the communes. The Mietków commune is an exception - underwater areas take second place. 
Table 1: $\quad$ The current manner of land use in the studied communes.

\begin{tabular}{|c|c|c|c|c|c|c|c|c|c|}
\hline \multirow[t]{3}{*}{ No. } & \multirow[t]{3}{*}{ Indicator } & \multicolumn{8}{|c|}{ Commune } \\
\hline & & \multicolumn{2}{|c|}{ Sobótka } & \multicolumn{2}{|c|}{$\begin{array}{l}\text { Jordanów } \\
\text { Śląski }\end{array}$} & \multicolumn{2}{|c|}{ Mietków } & \multicolumn{2}{|c|}{$\begin{array}{c}\text { Kąty } \\
\text { Wroclawskie }\end{array}$} \\
\hline & & $\mathbf{H a}$ & $\%$ & ha & $\%$ & $\mathbf{H a}$ & $\%$ & $\mathbf{H a}$ & $\%$ \\
\hline 1. & $\begin{array}{l}\text { Total area of } \\
\text { commune }\end{array}$ & 13535.00 & 100.00 & 5662.00 & 100.00 & 8330.00 & 100.00 & 16954.06 & 100.00 \\
\hline 2. & $\begin{array}{l}\text { Area of } \\
\text { commune } \\
\text { under } \\
\text { protection as } \\
\text { part of a } \\
\text { natural } \\
\text { landscape park }\end{array}$ & 4447.00 & 32.90 & 540.00 & 9.50 & 3188.00 & 38.30 & 4021.60 & 22.80 \\
\hline 3. & $\begin{array}{l}\text { Area used for } \\
\text { settlements }\end{array}$ & 590.00 & 4.36 & 360.00 & 6.36 & 220.00 & 0.26 & 614.14 & 3.62 \\
\hline 4. & Forest area & 2998.00 & 22.15 & 190.00 & 3.21 & 959.00 & 11.51 & 1227.28 & 7.24 \\
\hline & $\begin{array}{l}\text { Agricultural } \\
\text { land area }\end{array}$ & 9261.00 & 68.42 & 4900.00 & 86.54 & 5733.00 & 68.82 & 0.00 & 81.30 \\
\hline 5. & $\begin{array}{l}\text { Surface water } \\
\text { area }\end{array}$ & 174.00 & 1.28 & 27.00 & 0.47 & 1060.00 & 12.72 & 266.70 & 1.57 \\
\hline 6. & $\begin{array}{l}\text { Area used for } \\
\text { communicatio } \\
\mathrm{n}\end{array}$ & 481.00 & 3.55 & 175.50 & 3.09 & 310.00 & 3.72 & 615.59 & 3.63 \\
\hline 7. & $\begin{array}{ll}\text { Park greenery } \\
\text { area }\end{array}$ & 23.00 & 0.17 & 4.25 & 0.07 & 42.00 & 0.50 & 149.20 & 0.88 \\
\hline 8. & $\begin{array}{l}\text { Cemetery } \\
\text { greenery area }\end{array}$ & 8.00 & 0.06 & 4.00 & 0.07 & 6.00 & 0.07 & 17.14 & 0.10 \\
\hline
\end{tabular}

Source: own elaboration based on LDB data.

When grouping commune surfaces by their current manner of use according to the approved criteria of spatial policy evaluation with regard to ecosystem services, spheres for functions considered to be compensative or preventive were not properly identified. Regardless, part of the area of the Sobótka, Kąty Wrocławskie and Mietków communes utilise sewage systems connected to local sewage plants, which is considered preventive action. Figure 1 represents the current use of space in the studied communes with regard to approved ecosystem services.

In the current state of things, areas dedicated for purposes classified in the services for the benefit of the ecosystem group (through letting them be as they are, through doing nothing) are definitely dominant in the studied communes. Developed areas, classified in the areas providing services for the benefit of humans group, are a small share of the total categorisation of areas designated for various purposes. Such manner of land use seems to be beneficial to the communes when it comes to environmental protection. Yet, it lacks preventive actions; or perhaps they are overlooked and hard to identify. 


\section{Ecosystem services planned in the spatial policy of the communes}

The spatial policy established within each commune allowed for the measuring the areas planned for functional purposes. These are grouped according to ecosystem services (table 2). Documents defining the spatial policy in the communes are the basis of formulating local plans, which are formally used in Poland to grant building permits. Spatial policy is thus an important element in planning the spatial development of communes.

Table 2: The area and share of planned functions in the communes with regard to approved ecosystem services.

\begin{tabular}{|c|c|c|c|c|c|c|c|c|c|}
\hline \multirow[t]{3}{*}{ No. } & \multirow[t]{3}{*}{ Indicator } & \multicolumn{8}{|c|}{ Commune } \\
\hline & & \multicolumn{2}{|c|}{ Sobótka } & \multicolumn{2}{|c|}{ Jordanów Śląski } & \multicolumn{2}{|c|}{ Mietków } & \multicolumn{2}{|c|}{$\begin{array}{c}\text { Kąty } \\
\text { Wroclawskie }\end{array}$} \\
\hline & & ha & $\%$ & ha & $\%$ & $\mathrm{Ha}$ & $\%$ & $\mathrm{Ha}$ & $\%$ \\
\hline 1. & $\begin{array}{l}\text { Total area of } \\
\text { commune }\end{array}$ & 13535.00 & 100 & 5662.00 & 100 & 8330.00 & 100 & 16954.06 & 100 \\
\hline 1. & \multicolumn{9}{|c|}{ Ecosystem service for the benefit of humans (Latin dare) } \\
\hline 1.1. & $\begin{array}{l}\text { Areas } \\
\text { designated for } \\
\text { residential- } \\
\text { service } \\
\text { construction }\end{array}$ & 2212 & 16.34 & 800 & 14.13 & 440 & 5.28 & 3760 & 22.17 \\
\hline 1.2 . & $\begin{array}{l}\text { Areas } \\
\text { economic } \\
\text { activity }\end{array}$ & 640.00 & 4.72 & 290.00 & 5.12 & 76.00 & 0.91 & 2034.00 & 12.00 \\
\hline 1.3 . & $\begin{array}{l}\text { Areas } \\
\text { surface } \\
\text { exploitation }\end{array}$ & 2.00 & 0.01 & 4.50 & 0.08 & 98.00 & 1.17 & 105.00 & 0.61 \\
\hline 1.4 . & $\begin{array}{l}\text { Areas for } \\
\text { communication }\end{array}$ & 481.00 & 3.55 & 175.00 & 3.09 & 310.00 & 3.72 & 808.00 & 4.46 \\
\hline 1.5 . & Tourist areas & 220.00 & 1.62 & 82.00 & 1.45 & 127.50 & 1.53 & 0.00 & 0.00 \\
\hline \multirow[t]{2}{*}{1.6.} & $\begin{array}{l}\text { Cemetery } \\
\text { greenery areas }\end{array}$ & 15.00 & 0.10 & 4.00 & 0.07 & 6.00 & 0.07 & 18.00 & 0.11 \\
\hline & TOTAL: & 3570.00 & 26.34 & 1355.50 & 23.94 & 1014.50 & 12,68 & 6725.00 & 39.35 \\
\hline 2. & \multicolumn{9}{|c|}{$\begin{array}{c}\text { Human service for the benefit of the ecosystem (compensation) doing something (Latin facere), } \\
\text { not doing something (non facere) }\end{array}$} \\
\hline 2.1 & Forest areas & 2998.00 & 22.14 & 190.00 & 3.35 & 959.00 & 11.51 & 1227.00 & 7.23 \\
\hline 2.2 . & $\begin{array}{l}\text { Agricultural } \\
\text { land }\end{array}$ & 6610.00 & 48.83 & 3999.50 & 70.63 & 5122.50 & 61.49 & 8579.06 & 50.58 \\
\hline 2.3 . & $\begin{array}{ll}\begin{array}{l}\text { Park } \\
\text { areas }\end{array} & \text { greenery } \\
\end{array}$ & 178.00 & 1.31 & 4.50 & 0.08 & 42.00 & 0.50 & 150.00 & 0.88 \\
\hline \multirow[t]{2}{*}{2.4 . } & $\begin{array}{l}\text { Underwater } \\
\text { areas }\end{array}$ & 174.00 & 1.28 & 27.00 & 0.47 & 1060.00 & 12.72 & 267.00 & 1.57 \\
\hline & TOTAL & 9960.00 & 73.56 & 4221.00 & 74.53 & 7183.50 & 86.22 & 10223.06 & 60.26 \\
\hline 3. & \multicolumn{9}{|c|}{ Preventive and retardant actions (Latin pati) } \\
\hline 3.1. & $\begin{array}{l}\text { Areas for } \\
\text { planned } \\
\text { afforestation }\end{array}$ & 0.00 & 0.00 & 82.00 & 1.45 & 86.50 & 1.03 & 0.00 & 0.00 \\
\hline 3.2 . & $\begin{array}{l}\text { Sewage plant } \\
\text { areas }\end{array}$ & 4.00 & 0.03 & 2.50 & 0.04 & 2.00 & 0.02 & 2.00 & 0.01 \\
\hline 3.3 & Landfill areas & 1.00 & 0.01 & 1.00 & 0.01 & 1.00 & 0.01 & 4.00 & 0.02 \\
\hline & TOTAL & 5.00 & 0.04 & 85.50 & 1.50 & 89.50 & 1.06 & 6.00 & 0.03 \\
\hline
\end{tabular}

Source: own elaboration. 
In all studied communes, among the planned development spheres, those concerned with actions based on not doing something (non facere) are dominant. Nevertheless, a large portion of the area is designated for transfer into the ecosystem services for the benefit of humans group. These areas constitute almost $40 \%$ of total area in Kąty Wrocławskie, with the current area of $7.35 \%$; in Sobótka they would take up $26.34 \%$ with the current area being $7.95 \%$. The lowest share in total area is planned for the Mietków commune.

Preventive actions have been observed in each commune, in the form of designating areas for sewage plants and landfill.

Restorative activities show the worst results. These also include afforestations which are lacking in Sobótka and Kąty Wrocławskie. It is especially worrying in Kąty Wrocławskie due to a relatively low forest density of the commune (around $7.23 \%$ ). An alarmingly small amount of forest areas is also the case of Jordanów Śląski (only 3.35\%). Even proper afforestation in accordance with the approved spatial policy will not improve the forest density indicator in this commune.

Figure 2 shows the overall division of areas in the communes according to approved criteria of ecosystem services.

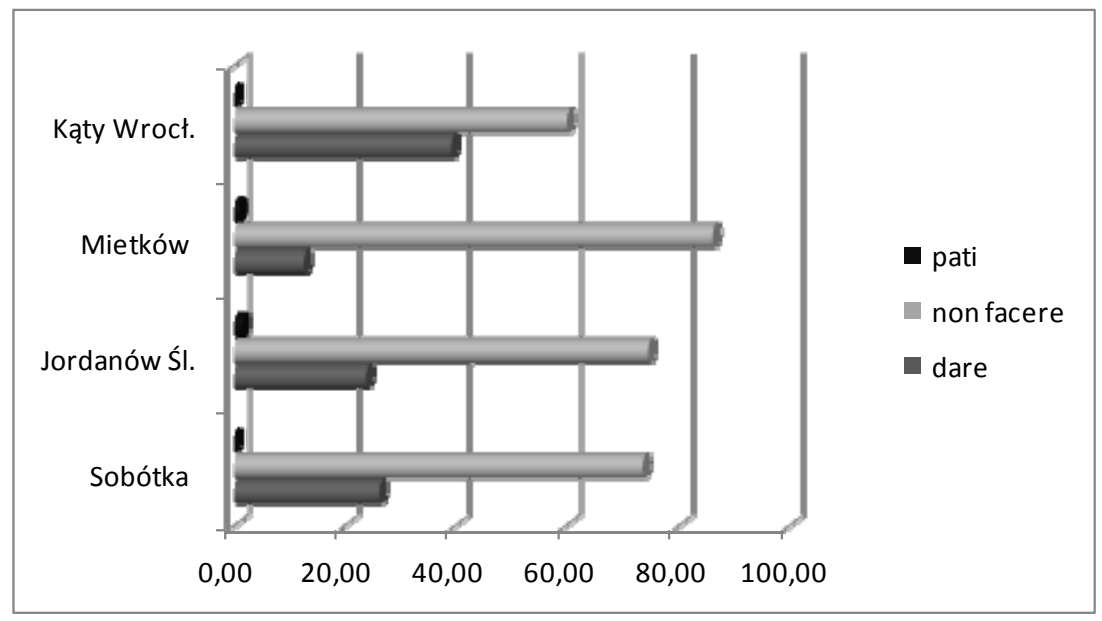

Figure 2: The planned manner of land use in the spatial policy according to ecosystem services.

The distribution of ecosystem services in the spatial policy of the communes is definitely changing in relation to the current manner of land use. One might assert that the least favourable model of sphere distribution can be found in Katy Wrocławskie, where the planned structure of land use in the ecosystem services for the benefit of humans group (Latin dare) in relation to areas from the human services for the benefit of the ecosystem group based on the principle of not doing anything (Latin non facere) can equal 2 to 3. An alarming growth of urbanised space is also planned, which is the consequence of suburbanisation processes in the neighbouring city of Wrocław. The planned structure in the next 
communes, including Sobótka and Jordanów, also presents an unfavourable image. What is planned there is an almost double increase in the share of areas from the ecosystem services for the benefit of humans group, which would result in a decrease in areas from the sphere related to human services for the benefit of the ecosystem through doing nothing (Latin non facere). The planned changes practically do not involve any preventive action. The indicated areas designated for afforestation do not compensate for the losses in the biologically active surface in any way.

\section{Conclusions}

The proposed model of ecosystem services can serve as a tool for evaluating the established spatial policy on a local level and for discussing the course of action towards further spatial formation of the commune. The project can be successfully applied in communes on the stage of formulating its spatial policy. Local authorities should know the balance of planned development spheres.

The study showed that the introduction of environmental protection into each commune in the form of natural landscape parks achieved little to nothing when it comes to its influence on the planning of spatial development in the overall balance of commune areas. A detailed analysis has proved, however, that the appearance of new construction developments in the parks in the Kąty Wrocławskie, Mietków and Jordanów commune is limited, and more decisive in Sobótka. The Mietków commune achieved the most favourable results in the overall evaluation of planned functional spheres.

The arrangement of functional areas in the studied communes currently applies only in the sphere of spatial policy and has not yet been put to life. Its realisation might bring about very negative consequences for the environmental cycle. An architectural convolution of such magnitude within the borders of the landscape park in Sobótka should have never taken place. One can only hope that these intentions will never come to life.

\section{Acknowledgements}

The research has been conducted as part of a research project entitled "Ecosystem services in the environmental development of the Wrocław poviat communes in the context of communes located in landscape parks. Modelling changes - theoretical and practical assumptions." Registration number: N N305 103840 .

\section{References}

[1] Solon J. The "Ecosystem Services" concept and its application in landscape-ecological studies. http://www.paek.ukw.edu.pl. Warsaw. [in Polish] 
[2] Mizgajski A., Stępniewska M., 2009. The ecosystem services concept and the implementation of sustainable development. The ecological problems of sustainable development. Kiełczewski D., Dobrzańska B. (Eds.), Białystok School of Economics Publishing, p. 12-23. [in Polish]

[3] Costanza R., D’Arge R., De Groot R., Farberk S., Grasso M., Bruce Hannon B., Limburg K, Naeem S., O’Neill R.V., Paruelo J., Raskin R.G., Suttonkk P., van den Belt M. 1997. The value of the world's ecosystem services and natural capital. Nature, No. 387, p. 253-260.

[4] De Groot R.S., Wilson M.A., Boumans R.M. J. 2002. A typology for the classification, description and valuation of ecosystem functions, goods, and services. Ecological Economics 41:393-408.

[5] Daily G.C. (Ed.) 1997. Nature's services: societal dependence on natural ecosystems. Island Press, Washington DC.

[6] Cork S.J. 2001. Ecosystem services. The many ways in which biodiversity sustains and fulfills human life. [In:] Food for Healthy People and a Healthy Planet, Internet conference organised by the Nature and Society Forum.

[7] Kremen C. 2005. Managing ecosystem services: what do we need to know about their ecology? Ecology Letters 8: 468-479.

[8] Lyons K.G., Brigham C.A., Traut B.H., Schwartz M.W. 2005. Rare Species and Ecosystem Functioning. Conservation Biology 19, 4, 1019-1024.

[9] Maass J., Balvanera P., Castillo A., Daily G.C., Mooney H.A., Ehrlich P., Quesada M., Miranda A., Jaramillo V.J., García-Oliva F., Martínez-Yrizar A., Cotler H., López-Blanco J., Pérez-Jiménez A., Búrquez A., Tinoco C., Ceballos G., Barraza L., Ayala R., Sarukhán J. 2005. Ecosystem services of tropical dry forests: insights from long-term ecological and social research on the Pacific Coast of Mexico. Ecology and Society 10(1): 17. [online] URL: http://www.ecologyandsociety.org/vol10/iss1/art17/

[10] Brenner-Guillermo J. 2007. Valuation of ecosystem services in the Catalan coastal zone. Doctorate dissertation. Marine Engineering Laboratory [Laboratori d'Enginyeria Marítima] of the Polytechnic University of Catalonia [Universitat Politècnica de Catalunya], Barcelona 178 pp. [http://www.tdx.cesca.es]

[11] Meyerson L.A., Baron J., Melillo J.M., Naiman R.J., O’Malley R.I., Orians G., Palmer M.A., Pfaff A.S.P., Running S.W., Sala O.E. 2005. Aggregate measures of ecosystem services: can we take the pulse of nature? Front. Ecol. Environ. 3(1): 56-59.

[12] MEA 2005. Ecosystems and Human Well-being: Current State and Trends, Volume 1. Findings of the Condition and Trends. Working Group of the Millennium Ecosystem Assessment. Island Press Washington, Covelo, London. pp. 917. 